\title{
'The biggest mistake God ever made was to create junkies': Unsafe injection practices, health care discrimination and overdose deaths in Montreal, Canada
}

\author{
Ehsan Jozaghi \\ Simon Fraser University, School of Criminology
}

\begin{abstract}
Despite the existence of prevention programmes in Montreal, Canada, injection drug users (IDUs) continue to share their injection drug equipment. This practice has led to an increase in the incidences of HIV and Hepatitis C (HCV) among IDUs since 2003. The present study was conducted to explore factors contributing to the increased risks of this morbidity. Semi-structured qualitative interviews were conducted as drug users were actively involved in their routine activities. The participants' narratives indicate that IDUs in Montreal are involved in risky injection behaviour that increases HIV, HCV and bacterial transmission. Moreover, IDUs in Montreal are at an increased risk of overdose and death when they are forced to inject in public washrooms or alleys. In addition, many IDUs have placed the general public at risk by discarding their used needles in public parks, sidewalks and public washrooms. Furthermore, many IDUs in Montreal have faced discrimination and are refused treatment by the health care system. Microenvironmental factors, such as a paucity of safe injection sites, inaccessibility of injection equipment and discrimination all seem to be contributing factors in recent increases in HIV and HCV in Montreal.
\end{abstract}

Keywords: supervised injection facility; harm reduction; drug policy

Malgré les programmes de prévention qui existent à Montréal, Canada, les utilisateurs de drogues injectables (UDI) continuent de partager leurs seringues. Cette pratique a mené à une augmentation de l'incidence du virus de l'immunodéficience humaine (VIH) et du virus de l'hépatite C (VHC) parmi les UDI depuis 2003. La présente étude a été menée afin d'examiner les facteurs qui contribuent à l'augmentation des risques de cette morbidité. Des entretiens qualitatifs semi-directifs ont été réalisés pendant que les utilisateurs faisaient usage de drogues. Les commentaires recueillis auprès des participants ont confirmé que les UDI de Montréal adoptent des comportements d'injection qui augmentent les risques de contracter le VIH et le VHC en plus de faciliter la transmission de bactéries. De plus, le risque de surdose et de mort est plus élevé chez les UDI de Montréal lorsqu'ils sont forcés de s'injecter des drogues dans des toilettes publiques ou dans des ruelles. En outre, de nombreux UDI compromettent la sécurité du public en jetant leurs seringues dans les parcs publics, sur les trottoirs ou dans les toilettes publiques. Par ailleurs, de nombreux UDI de Montréal ont été victimes de discrimination et se sont vus refuser l'accès à des traitements par le système de santé publique. Des facteurs micro-environnementaux, tels que la rareté de sites d'injection supervisés, l'inaccessibilité aux seringues et la discrimination, s'avèrent tous des facteurs qui semblent contribuer à l'augmentation récente de l'incidence du VIH et du VHC à Montréal.

Mots-clés: site d'injection supervisé; réduction des préjudices; politique en matière de drogues 


\section{Introduction}

The illegal drug trade continues to fuel crime, gang violence and drug addiction. Annually, it is estimated that between 155 and 250 million people worldwide use illegal substances (International Centre for Science in Drug Policy, 2010). In Canada alone, it is estimated that there are more than 125,000 injection drug users (IDUs), who are affected by poverty, homelessness and mental illness (Fischer et al., 2006; Kerr et al., 2003). Illegal drug injection in Canada has been associated with extensive harms to both the user and taxpayers. In fact, Canada's cost of illegal drugs was approximately $\$ 8.2$ billion dollars whereas the cost of illegal drug injection was estimated to be $\$ 1.4$ billion per year (Rehm et al., 2006; Wall et al., 2000).

IDUs are at an elevated risk of morbidity (i.e. infectious diseases including human immunodeficiency virus (HIV) and hepatitis C (HCV)) (Wall et al., 2000). In Canada, for example, the annual incidence and prevalence rate of HIV transmission related to IDUs have been estimated between 20 percent (Roy et al., 2012). HCV rate are even higher, estimated to be around 60 percent (Roy et al., 2012). In addition to the spread of infectious diseases, drug overdose resulting in death is a huge problem in Canada. For example, from 2002 to 2003, it was estimated that 958 people died of a drug overdose (Popova, Patra, Mohapatra, Fischer \& Rehmn, 2009).

The situation has been particularly problematic in Montreal, Canada, where IDUs continue to share their injection drug equipment despite Montreal's liberal needle exchange program (NEP), that does not limit the number of syringes that can be obtained and the availability of low cost syringes through pharmacies (De et al., 2009; Green, Hankins, Palmer, Boivin \& Platt, 2004). According to Morissette et al. (2007), Montreal has 11 NEPs, 11 community health centres, two methadone clinics and 150 pharmacies that distribute approximately 800,000 syringes. Despite these services, recent data from Montreal indicates rising incidence of HIV and HCV among IDUs since 2003 (Bruneau, Daniel, Kestens, Zang \& Généreux, 2008). Furthermore, Montreal is experiencing a drug overdose epidemic of up to 70 documented deaths per year (Jozaghi, 2012b).

As a result of this growing epidemic, the present study was conducted to explore factors contributing to increased risks of morbidity and mortality in Montreal. The current research aim to critically examine and identify themes in the lives, stories and circumstances of the most marginalized IDUs (e.g., homeless, HIV and HCV). It is hypothesised that ethnographic immersion, such as the current study, would allow for reporting of far more risky practices than the public health literature routinely reports (Bourgois, 1998). This qualitative research study draws on a small sample of participants; it does not claim to do the work of large quantitative studies in which representativeness and generalizability are defined (Jozaghi, 2012a). Nevertheless, themes are identified and recognized as meaningful, whether or not they apply in all cases. In fact, according to Small (2009), "there is a place for a small interview study to make a meaningful contribution to knowledge ... [since] rare situations are often precisely what the researcher wants" (p. 18). In effect, the purpose of this qualitative study is to understand each individual case and participants' perspectives, not to generalize the findings (Burawoy et al., 2000).

\section{Methods}

The current study was conducted in the city of Montreal, which has a land base of $500 \mathrm{~km}^{2}$ and a population of 1.8 million residents (Genereux, Bruneau \& Daniel, 2010). The Island of Montreal is the largest city in the province of Quebec and the second largest city in Canada (de Bibiana et al., 2011). Montreal is divided into 27 boroughs; the Ville-Marie borough and the Sainte-Marie 
neighbourhood are the most active injection drug use areas in the city. It is not surprising that these areas also have the highest levels of socioeconomic disadvantage and crime (Genereux et al., 2010; Montigny, Moudon, Leigh, \& Kim, 2011). A 2001 study estimated Montreal's IDU population to be between 4,300 and 12,500 individuals (Archibald et al., 2001; Green et al., 2004).

Beginning in February 2012, individuals living in Montreal who had injected illicit drugs in the previous month were recruited to participate in the study. This study was approved by Simon Fraser University's Research Ethics Board. Participants were eligible to partake in the study if they had injected illicit drugs at least once in the previous month, were 19 years of age or older and provided informed oral consent. Oral consent was provided by the participants to demonstrate that they have voluntarily participated in the research. Compensation of ten dollars was provided to each participant. Participants involved in drug use can reveal sensitive information about their criminal lifestyles and HIV or HCV status during interviews. Therefore, in order to protect the confidentiality of participants, all names used in this paper are pseudonyms.

In order to explore IDU perspectives, the study drew upon data from semi-structured qualitative interviews. Key informants/gatekeepers were used to help achieve the desired sampling techniques; in this case, purposive and snowball sampling. Key informants were peer IDUs who volunteered at the needle exchange depots in Montreal. As a result, they were familiar with many of the homeless clients in different parts of the city. Three peer IDUs were chosen to facilitate the selection process. The key informants also had local knowledge and subsequent references to friends and acquaintances that were extremely effective in ensuring some variation within the sample (see Table 1).

As Esterberg (2002) explains, chain referral may be the only way to recruit interviewees for "hidden" populations or groups of people who engage in stigmatizing behaviour. In the current study, more than 70 percent of the sample was homeless and contributed enormously to some of the key issues identified in this paper. For example, the homeless participants were able to address issues related to public injection, sharing and discarded syringes. IDUs who were homeless also addressed issues related to accessibility of clean syringes and risk of overdose (compared to those who choose to inject at home). A total of 18 IDUs were approached and all 18 agreed to be interviewed. All participants were interviewed once. The participants were recruited off the street in areas were IDUs are known to congregate. Two participants were recruited from a social housing unit, and the remaining sample was comprised of people who visited Spectre de rue (needle depot) located in the Sainte-Marie neighbourhood and Cactus (needle depot) on Rue SainteCatherine. This selection process allowed for some variation within a small sample because participants represented different geographical areas of Montreal.

The open-ended, semi-structured interviews were facilitated through the use of an interview guide. The interview guide was used to encourage discussion about life as an IDU, the impact of not having a safe place to inject given the nature of the behaviour involved, and to elicit suggestions related to the ways in which the risky behaviour could be reduced. The questions were chosen based on previous work that has been done in the realm of harm reduction research. All participants seemed genuinely interested in the interview and shared their unique experiences and individual examples that shaped the direction of the interview. In all of the interviews conducted, topics came out of natural conversations and as suggested by Berg (2009), deviations were explored as they arose. This resulted in several unexpected discussions, such as intentional overdose referred to as 'hot cap' by participants. 
Table 1.

Characteristics of the sample of IDUs in Montreal

\begin{tabular}{|c|c|c|}
\hline & $n$ & $\%$ \\
\hline \multicolumn{3}{|l|}{ Age } \\
\hline $20-30$ & 6 & 33.3 \\
\hline $31-40$ & 2 & 11.1 \\
\hline $41-50$ & 5 & 27.8 \\
\hline $51-60$ & 5 & 27.8 \\
\hline \multicolumn{3}{|l|}{ Gender } \\
\hline Male & 16 & 88.9 \\
\hline Female & 2 & 11.1 \\
\hline \multicolumn{3}{|l|}{ Ethnicity } \\
\hline Caucasian & 15 & 83.3 \\
\hline Black & 1 & 5.6 \\
\hline First Nation & 2 & 11.1 \\
\hline \multicolumn{3}{|l|}{ Resides in Montreal } \\
\hline Yes & 12 & 66.7 \\
\hline No & 6 & 33.3 \\
\hline \multicolumn{3}{|l|}{ Number of injection perd day $(X)$} \\
\hline$x \leq 2$ & 5 & 27.8 \\
\hline $2<x \leq 5$ & 5 & 27.8 \\
\hline$x>5$ & 8 & 44.4 \\
\hline \multicolumn{3}{|l|}{ Years of injection (Y) } \\
\hline$Y \leq 5$ & 5 & 27.8 \\
\hline $5<Y \leq 10$ & 4 & 22.2 \\
\hline$Y>10$ & 9 & 50 \\
\hline \multicolumn{3}{|l|}{ Medical Condition } \\
\hline Nil & 6 & 33.3 \\
\hline $\mathrm{HIV} \& \mathrm{HCV}$ & 7 & 38.9 \\
\hline $\mathrm{HCV}$ & 5 & 27.8 \\
\hline
\end{tabular}


Table 1. Continued

\begin{tabular}{|c|c|c|}
\hline & $r$ & $\%$ \\
\hline \multicolumn{3}{|l|}{ Drug of choice } \\
\hline Cocaine & 9 & 50 \\
\hline Cocaine and Heroin & 5 & 27.8 \\
\hline Heroin & 2 & 11.1 \\
\hline Other & 2 & 11.1 \\
\hline \multicolumn{3}{|l|}{ High school Education } \\
\hline Yes & 7 & 38.9 \\
\hline No & 11 & 61.1 \\
\hline \multicolumn{3}{|l|}{ Criminal Record } \\
\hline Yes & 14 & 77.8 \\
\hline No & 4 & 22.2 \\
\hline \multicolumn{3}{|l|}{ Unemployed } \\
\hline Yes & 18 & 100 \\
\hline No & 0 & 0 \\
\hline \multicolumn{3}{|l|}{ Sex trade in the last 6 months } \\
\hline Yes & 3 & 16.7 \\
\hline No & 15 & 83.3 \\
\hline \multicolumn{3}{|l|}{ Money/drugs for sex in the last 6 months } \\
\hline Yes & 9 & 50 \\
\hline No & 9 & 50 \\
\hline \multicolumn{3}{|l|}{ Relationship Status } \\
\hline Single/divorce & 16 & 88.9 \\
\hline Married/common Law & 2 & 11.1 \\
\hline \multicolumn{3}{|l|}{ Mother Tongue } \\
\hline French & 16 & 88.9 \\
\hline English & 2 & 11.1 \\
\hline \multicolumn{3}{|l|}{ Principal Dwelling place } \\
\hline Private residence or other's house & 5 & 27.8 \\
\hline Street & 13 & 72.2 \\
\hline
\end{tabular}

The interview process involved four thematic dimensions: (1) experience on the street; (2) injection behaviour; (3) overdose risk (4) drug use culture; followed by an open discussion about anything raised during the interview. Their responses were audio recorded and were later transcribed verbatim. To reduce distortion of the data due to social desirability of responses, interviews were conducted in a conversational format as drug users were actively involved in their routine activities.

The qualitative data were reviewed and all text segments were subsequently subjected to a thematic analysis using NVivo 9 software. A "tree" node was created for general themes resulting from an inductive search. A "free" node was deductive or emergent and came from general observations, which resulted in more specific categories. Free nodes were created after tree nodes 
were searched. Silverman \& Marvasti (2008) caution against the tendency for coding schemes to become "powerful conceptual grid[s] from which it is difficult to escape" (p.225). Therefore, each time a theme was referenced, the software gave it a number and percentage. A word frequency query was also completed to view the most frequently used words. This organization and analysis of the data allowed for the most dominant themes to be identified.

Interviews were listened to several times before importing and transcribing them into the NVivo 9 software. To ensure reliability and reduce any bias, two different researchers conducted the coding in two different ways. The initial coding method involved the first coder identifying themes without computer software. For example, the transcripts were printed to visually look for common words and themes with highlighters. The themes identified by the first coder were later compared to the themes identified by the second coder using NVivo 9.

\section{Findings}

\section{Risky behaviour}

The most frequent narrative offered by participants in this study was the tendency to share needles. In fact, some of the participants reported contracting $\mathrm{HIV} / \mathrm{HCV}$ through sharing needles. For example, according to Mike:

I have Aids ... I got it through sharing drugs. I remember, I was hanging around the shooting galleries in Montreal and at one point in time, I remember I walked into a room - this was the last week of my crazy consumption - I found one syringe on the ground, I picked it up, looked at it for a bit, it had a little bit still left inside, but it was crooked. I fixed it and did my hit without any regard if it had HIV or any sickness in it what so ever. I had reached a point of my life that I didn't care anymore.

According to Stein, Dubyak, Herman, and Anderson (2007), to reduce physical discomfort, IDUs will sometimes use drug residue from other users' equipment with a disregard of the users' HCV/HIV status. In effect, sharing behaviours within the IDU population is an established factor that has led to substantially higher risks of HIV infection, even if practiced relatively infrequently (Des Jarlais \& Semaan, 2002).

Some of the participants indicated that craving for drugs, especially cocaine or as they called it 'jonesing', forces some users to use other persons' needles. As Alberto explains:

Usually you don't think about the risk of HIV when you're high. Before you're high you think about the risk, but when I am high I don't care. I just say, you have one hot for me, and he just took it out of his arm, OK, Put it in me. So you just want that next fix without even thinking about HIV. That's how most junkies get Hep C or HIV.

Previous research in the realm of IDUs has also reported on 'jonesing' (Shannon et al., 2007). In the case of cocaine injection, jonesing behaviour may be partially attributed to "cocaine's short half-life reflecting the desire to inject often in order to continuously feel the effects of the drug" (Rachlis et al., 2010, p. 1385). Furthermore, the majority of participants believe that the risky behaviour described above is mainly attributed to a lack of clean needles in Montreal. Given that the two needle 
depots in downtown Montreal (e.g., Cactus and Spectre de rue) have limited operating hours, this inconvenience forces many addicts to borrow or rely on used syringes. Jason describes this scenario:

The most time you see people share is before 4, because after 4 o'clock you got Cactus on SainteCatherine that gives free needles, but other than that, you have to buy them in pharmacies for a buck for a package [contains four needles and condoms]. Other than that people share, like on the day time they don't give a shit. Like if they're sick, they just use somebody else's rig ... I've even seen people pick up rigs on the floor and do their hit. And this is 2012 and I still see that. I've never seen that in Vancouver because there is so many exchange over there, but here I still see people picking up rigs on the floor.

Indeed, people in Vancouver's Downtown Eastside (DTES) are less likely than people in Montreal to report frequent syringe borrowing because the needle depot operating in Vancouver's DTES is one of the largest in North America (Strathdee et al., 1997). High risk IDUs in Montreal, according to Jason, prefer the first available needle to the first available clean needle provided at the nearby needle depot a few kilometres down the alley. Many participants, report that some addicts will use their friend's injection kit despite their knowledge of the person's HIV status:

I had people ask me for my needles and everybody knows that I am HIV positive. And I always tell everybody. So they know. If I turn my back people always try to steal my hit ... but people just don't care.

Sharing non-injection equipment, such as spoons or cookers described above, places many addicts at high risk of HIV or HCV infection. In addition, many participants report observing other risky behaviours, such as using puddle water for injection. As Michael suggests:

I have seen people take their water from the street, they take their cotton [filter] and take the water from the ground. Its filthy, It's horrible ... I know people that have got meningitis after using puddle water in Montreal.

Ringertz et al. (2000) also report the high prevalence of meningitis among the IDU population (p. 1574). In addition, according to Lurie, Gorsky, Jones and Shomphe (1998) and Lloyd-Smith et al. (2008), unhygienic injections as described above are a risk factor for cellulitis, subcutaneous abscesses, endocarditis, and softtissue infections. Therefore, having a supervised injection facility (SIF) would help reduce risky behaviours. As Stoltz et al.'s (2007) study has demonstrated, "more consistent SIF use is associated with positive changes in injecting practices, including less reusing of syringes, use of sterile water, [and] cooking/filtering [of] drugs" (p. 35).

\section{Overdose}

The majority of participants indicated that they have either experienced an overdose or have witnessed an overdose. In the case of Alex, the overdose experience is a recent one:

Once a week there is an overdose, I overdosed quite a few times in one of these washrooms and there is nobody there to help you ... you basically slowly die without anybody noticing you. 
Similarly, participants indicated that they have lost friends as a result of an overdose. Since the majority of IDUs are injecting drugs in secluded areas, such as bathrooms or behind dumpsters, no one is usually present to provide assistance to a user who has been overdosed. And, in most cases, an overdose in Montreal leads to death. IDUs do not have the knowledge or expertise to help someone in an overdose situation. Furthermore, IDUs do not have access to a cell phone or a public phone to call 911. For example, according to Mike:

OD risk and dying as a result in back alleys, washrooms and metro stations is the reality in Montreal. There is nobody to help you ... It's scary ... With the smack [heroin] don't let them sleep because if they sleep, they never going to wake up ... and I have lost a few friends to overdose and I hear about OD death in Montreal quite often ... beginning of last summer, I lost my best friend James to overdose.

Participants attributed overdose to the fear of police and risk of arrest. In effect, according to Michael, if addicts had a safe place to inject, they would have time to do a smaller dose that could ultimately prevent overdose death:

They do too much dope because they don't have a safe place to put their dope, so they do all their dope, y'know they don't want to have all their dope on them because the cops are busting and they end up ODing and dying as a result ...

I've seen one person who had a needle sticking out of his arm for three days stock in a back doorway of business sleeping outside and people where going by for three days without stopping to know whether he was OK or not. And It was by chance that I noticed that he was there and I pushed the person to see if he was OK and he was White as a sheet of a paper. He was dead with needle still stock in his arm and people left him there like he was a garbage bag.

Stoltz et al.'s (2007) study reported that opening a SIF results in fewer rushed injections. Marshall et al.'s (2011) study showed that overdose mortality was reduced after the opening of InSite in Vancouver. Overdose reductions are most notable in the vicinity of the facility with over a 35 percent reduction within 500 meters of InSite (Marshall et al., 2011). Moreover, people who overdose are at a greater risk of being victims of theft. For instance, according to Gary, overdose has been used as a method by some dealers to prey on the vulnerable IDU population by selling heroin to coke users to force an overdose:

They call it a hot cap, what they do is they're coke addict, but they sell them two points of smack [heroin], OD them, and take their welfare cheque out of their pocket. I know few people that have been murdered for few hundred welfare cheque. And when the police find them, they think that Oh it's just another junkie who ODed.

Situations like the ones previously described demonstrate the need for a supervised injection location where trained staff and nurses would be available to assist overdose patients and to help reduce deaths associated with overdose. As Kerr et al. (2007) suggest, "SIFs can address many of the micro- environmental factors that drive overdose risk and limit individual ability to employ overdose prevention practices" (p. 37). 


\section{Landscape}

According to the IDUs participating in this study, public injection is a huge problem in Montreal. Participants indicated that they are forced to inject in public places because no other places are available to use. In fact, some of them, like Ruby, are ashamed that they have to inject under the watchful eyes of public:

Everybody injects outside in Montreal. Between Papineau and Saint-Laurent and Rene- Levesque and Sherbrooke it's the place for junkies to shoot because there are back streets everywhere. But ... we don't do it to cause trouble; we do it because we have no other safe place to go ... The biggest mistake God ever made was to create junkies.

Further, many of the participants indicted that they are forced to inject in public during extremely cold winters in Montreal. In the cold, according to Michael, many users freeze to death because they simply do not have a safe place to inject:

I know people that do their dope, fall sleep outside and they froze to death. Like I found one of my friend in a snow bank like that. So he did his hit of heroin he nodes, fall sleep, he froze to death. I am not fucking kidding. He literally froze to death. And it wasn't even the winter time. And this happens frequently in Montreal.

Many addicts, who are not willing to brace the cold, rely on metro stations and public washrooms to inject. However, injecting drugs in public washrooms can lead to rushed injection that may result in overdose. In addition, public injection can lead to police arrest. For instance, as Sam describes:

When you are in the washroom, you constantly worry if you're taking too long, people may be knocking on the door telling you to hurry up, you might even do a bigger wack. You might even miss. There is a chance of overdose too. You get paranoid ... I worry about getting caught. Like some of these people don't take no for an answer, they start banging on the door yelling, ... and they open the door and they see you off course with a needle sticking out of your arm and they all get scared and freak out, Ahhhhh and they go catch security, and then you get arrested.

Injecting in public, according to Stoltz et al. (2007), is a complex behaviour that increases environmental risk factors, such as rushed injections and the lack of sterile equipment and water. As a result, public injection has been shown to "increase risk for abscesses, syringe sharing, overdose, HCV infection and vein damage" (Stoltz et al., 2007, p. 38). Moreover, results demonstrate that "public injecting locations comprise a large network of alleyways, which are often unsanitary and constrain efforts to inject in a hygienic fashion" (Small, Rhodes, Wood, \& Kerr, 2007, p. 27). In fact, as James suggested earlier, many addicts due to fear of being hassled by the police and business owners, are preoccupied with "hurrying and worrying" when injecting in public, leading to increased risk of overdose (Small et al., 2007). Furthermore, based on participants' narratives like Michael, people who inject in public are putting families and pedestrians at risk by leaving their discarded injectable equipment in public places such as parks and sidewalks: 
It's disgusting, I see a lot people leaving their rigs behind every time they do a hit. They do their hit and they get all tweaked out, start looking around, start digging at something else and they forget about their shit and leave their stuff. And this is high risk because there are kids everywhere, people walking by. Who knows when a family is going to get out of their car and their toddler wonders off and falls on a needle.

Consequently, opening a SIF in Montreal would be beneficial since, according to Wood et al.'s (2004) study, the opening of the SIF "was independently associated with improvements in several measures of public order, including reduced public injection drug use and public syringe disposal" (p. 731). In addition, the opening of a SIF, according to Stoltz et al. (2007), would attract users who would otherwise be injecting in public spaces, such as parks or washrooms (p. 38).

\section{Violence/discrimination}

The previous discussion has outlined the daily risks of being an IDU in Montreal, such as the risk of overdose, HIV/ HCV risk behaviour, public injection and the risks of discarded syringes. However, there are several other problems associated with being an IDU. Many of the participants reported being mistreated or denied medical attention in hospitals due to their addiction problem. As Gary explains:

Saint-Luc hospital, they just red flag you, they won't even treat you ... I had a stomach full of blood. Plus I was covered in blood and blood was dripping from my back, they still refused to treat me there ... just because I am an IV addict.

In addition to the mistreatment experienced in hospitals, which seems to be the daily reality of street life for many IDUs, police harassment is another factor in their daily lives. For instance, according to Alex:

Animals get more respect than us ... we are hassled all the time by police ... they give us tickets all the time just for standing somewhere, they call it loitering, blocking passage, it's like a hundred something a ticket. There is a guy that has eighty, [or] ninety thousand dollars in tickets.

Two studies from Russia and Ukraine (countries with one of the most severe epidemic of HIV/AIDS in Europe) demonstrated that police practices directly violated health and human rights. Arbitrary police practices also indirectly reproduce the social suffering of the most marginalized IDUs (Mimiaga et al., 2010; Sarang, Rhodes, Sheon \& Page, 2010). Moreover, as James reports, police are very violent toward IDUs because of their drug using behaviour:

In Quebec it's really bad to be an IV user because the police ... [are] really violent towards addicts ...They're really aggressive ... and if the police catch you doing drugs in public places, they will hit you with their baton on the syringe to take it out of your control! It's really painful and then you get a ticket [interviewer: ticket for what?] For having consumed illicit drugs in public. I constantly worry about getting caught. 
Kerr, Small and Wood (2005) and Small, Kerr, Charette, Schechter, and Spittal (2006a) report that many IDUs who are forced to inject in public, rush their injections during periods of escalated police activity, a practice that further increases risk of abscesses, vascular damage and infection (p. 85). A number of studies also suggest that police activity is associated with limited access to clean syringes, accidental syringe sharing, and low access to needle exchanges, all of which impact the level of discarded syringes in the community (Small et al., 2006; Aitken, Moore, Higgs, Kelsall, \& Kerger, 2002; Calsyn, Saxon, Freeman, \& Whittaker, 1991).

\section{Discussion and Conclusion}

This study initially set out to examine factors that are contributing to the increased risks of morbidity and mortality in Montreal. The qualitative methods employed in this study, despite focusing on fewer cases, has produced a wealth of detailed information through careful description of events in the lives of IDUs. In fact, the findings reveal that the practice of sharing or borrowing needles is very common in Montreal. However, this practice has placed addicts at an increased risk of contracting HIV or HCV, thereby contributing to the recent increases in morbidity. Furthermore, many addicts are involved in risky injection behaviours, such as using puddle water for injection which increases the risk for meningitis, cellulitis, subcutaneous abscesses, endocarditis, and the occurrence of soft-tissue infections. Moreover, addicts in Montreal are at an increased risk of mortality when they are forced to inject in public washrooms or alleys. Many injection drug users are placing the public at risk by discarding their used needles in public parks, sidewalks and public washrooms.

IDUs are also facing discrimination in many hospitals in Montreal. IDUs in Montreal are also facing police brutality and harassment when they are involved in public injection. Increased police activity in Montreal and mistreatment of IDUs amplify the risks of engaging in public injections and rushed injectionsa practice that further increases the risk of abscesses, vascular damage, infection and overdose (Small, 2006). Consequently, having a SIF in Montreal would help reduce risky behaviour since, according to Stoltz et al.'s (2007) study, "more consistent SIF use is associated with positive changes in injecting practices, including less reusing of syringes, use of sterile water, [and] cooking/filtering [of] drugs" (p. 35). Kerr et al. (2007) also note that a possible SIF in Montreal "can address many of the micro-environmental factors that drive overdose risk and limit individual ability to employ overdose prevention practices" (p. 37). According to Wood et al.'s (2004) study, the opening of a SIF in Montreal could also improve public order, reduce public injection drug use and improve public syringe disposal. This prediction is based on the same results observed after opening North America's first SIF. Additionally, the opening of a SIF, according to Stoltz et al. (2007), would be attracting users who would otherwise be injecting in public spaces such as parks or washrooms.

Vancouver was the first North American city to open its doors to a SIF. On September $30^{\text {th }}, 2011$ the Supreme Court of Canada ruled in favour of InSite remaining open (Andresen \& Jozaghi, 2012). The experience of North America's first SIF convinced all the nine justices at the bench that

such a service could help avert the spread of infectious diseases, such as HIV, and assist the entry of IDUs into detoxification programs and prevent overdose deaths (Jozaghi, 2012b). More importantly, the ruling included provisions for future expansions of similar SIFs in Canada.

Buoyed by the recent Supreme Court's ruling regarding InSite and seen as a way to reduce community cost and public health and fiscal impacts of injection drug use, the Quebec government has shown interest in opening up SIFs in Montreal (Andresen \& Jozaghi, 2012). According to Quebec's Health and Social Services Minister, Yves Bolduc, SIFs "will offer services that will monitor the health of drug addicts and encourage them to seek detoxification and rehabilitation" 
(Jozaghi, 2012b, p. 1). Health officials in Montreal have proposed three SIFs in the city in addition to a mobile SIF for hard to reach populations (Jozaghi, 2012b). Success of this program, according to Jozaghi (2012b), depends on locating SIFs in areas where drug users live and in settings that currently deal with high rates of public drug use, such as Cactus and Spectre de rue (existing NEP locations) that are located in the central and oldest part of Montreal and have the highest levels of socioeconomic disadvantage.

In summary, micro-environmental factors such as the lack of safe places to inject, inaccessibility of injection equipment and police discrimination seem to be among the most common contributing factors in the recent increases of HIV and HCV in Montreal. The increase in morbidity rates in Montreal has taken place despite Montreal's long lasting NEPs. The result in Montreal is very similar to Vancouver's HIV and HCV epidemic rates during the late 1990s and early 2000s; increases in the aforesaid infectious diseases in Vancouver convinced the provincial and the federal governments to try to implement North America's first and Only SIF. As a result, similar to Vancouver, there is a need to open a SIF in Montreal to reduce the recent increases in HIV and HCV rates within the IDU population. Implementing a SIF should be based on the goals of preventing infectious diseases, improving care and safety by reducing risky behaviours, and preventing drug overdose deaths, violence, public injection, and discarded syringes in public. The willingness to use a SIF in this study highlights an important opportunity to connect with a known high-risk drug user population.

About the Author: Ehsan is a PhD student at the school of Criminology at Simon Fraser University. His research interests are harm reduction, drug policy, evaluation and research methods. Direct correspondence to: eja2@sfu.ca

\section{References}

Aitken, C., Moore, D., Higgs, P., Kelsall, J., \& Kerger, M. (2002). The impact of a police crackdown on a street drug scene: Evidence from the street. The International Journal of Drug Policy, 13, 193-202.

Andresen, M.A. \& Jozaghi, E. (2012). The point of diminishing returns: an examination of expanding Vancouver's Insite. Urban Studies, in press.

Archibald, C. P., Jayaraman, G. C., Major, C., Patrick, D. M., Houston, S. M., \& Sutherland, D. (2001). Estimating the size of hard-to-reach populations: A novel method using HIV testing data compared to other methods. AIDS, 15, S41-S48.

Berg, B. L. (2009). Qualitative research methods for the social sciences. Allyn \& Bacon: Toronto.

Bourgois, P. (1998). The moral economies of homeless heroin addicts: Confronting ethnography, HIV risk, and everyday violence in San Francisco shooting encampments. Substance use \& Misuse, 33(11), 2323-2352.

Bruneau, J., Daniel, M., Kestens, Y., Zang, G., \& Généreux, M. (2008). Association between HIV- related injection behaviour and distance to and patterns of utilisation of syringe-supply programmes. Journal of Epidemiol Community Health, 62, 804-810.

Burawoy, M., Blum, J. A., George, S., Gille, Z., \& Thayer, M. (2000). Global Ethnography: Forces, connections, and imaginations in a postmodern world . Berkeley: University of California Press.

Calsyn, D. A., Saxon, A. J., Freeman, G., \& Whittaker, S. (1991). Needle-use practices among intravenous drug users in an area where needle purchase is legal. AIDS, 5,187-93. 
De, P., Cox, J., Boivin, J. F., Platt, R. W., Jolly, A. M., Alexander, P. E. (2009). HIV and HCV discordant injecting partners and their association to drug equipment sharing. Scandinavian Journal of Infectious Diseases, 41, 206-214.

Des Jarlais, D. C., \& Semaan, S. (2002). HIV prevention research: Cumulative knowledge or accumulating studies? An introduction to the HIV/AIDS prevention research synthesis project supplement. Journal of Acquired Immune Deficiency Syndromes, 30(S1), S1-S7.

Esterberg, K. G. (2002). Qualitative Methods in social research. Toronto: McGraw-Hill.

Fischer, B., Rehm, J., Patra, J., Kalousek, K., Haydon, E., (...) \& Tyndall, M (2006). Crack across Canada: Comparing crack users and crack non-users in a Canadian multi-city cohort of illicit opioid users, Addiction, 101, 1760-1770.

Genereux, M., Bruneau, J., \& Daniel, M. (2010). Association between neighbourhood socioeconomic characteristics and high-risk injection behaviour amongst injection drug users living in inner and other city areas in Montreal, Canada. International Journal of Drug Policy, 21, 49-55.

Green, T. C., Hankins, C., Palmer, D., Boivin, J. F., \& Platt, R. (2004). My place, your place, or a safer place: The intention among Montreal injection drug users to use supervised injecting facilities. Canadian Journal of Public Health, 95(2), 110-114.

International Centre for Science in Drug Policy. (2010). Tools for debate: US federal government data on cannabis prohibition. Retrieved March 01, 2012, from: http://www.icsdp.org/docs/ICDP-2.pdf

Kerr, T., Small, W., Moore, D., \& Wood, E. (2007). A micro-environmental intervention to reduce the harms associated with drug-related overdose: Evidence from the evaluation of Vancouver's safer injection facility. The International Journal of Drug Policy, 18, 37-45.

Kerr, T., Small, W., \& Wood, E. (2005). The public health and social impacts of drug market enforcement: a review of the evidence. International Journal of Drug Policy, 16, 210-220.

Kerr, T., Wood, E., Palepu, A., Wilson, D., Schechter, M. T., \& Tyndall, M.W. (2003). Responding to an explosive HIV epidemic driven by frequently cocaine injection: Is there a role for safe injecting facilities? Journal of Drug Issues, 22(426), 579-608.

Jozaghi, E. (2012). 'A little heaven in hell': the role of a supervised injection facility in transforming place. Urban Geography, 33(8), 1144-1162.

Jozaghi, E. (2012). The science versus the politics: The need for supervised injection facilities in Montreal, Canada. International Journal of Drug Policy, 23, 420-421.

Lloyd-Smith, E., Wood, E., Zhang, R., Tyndall, M. W., Montaner, J. S. G., \& Kerr, T. (2008). Risk factors for developing a cutaneous injection-related infection among injection drug users: a cohort study. BMC Public Health, 8(405), 1-6.

Lurie, P., Gorsky, R., Jones, T. S., \& Shomphe, L. (1998). An economic analysis of needle exchange and pharmacy-based programs to increase sterile syringe availability for injection drug users. Journal of Acquired Immune Deficiency Syndromes and Human Retrovirology, 18(1), S126-S132.

Marshall, B. D. L., Milloy, M. J., Wood, E., Montaner, J. S. G., \& Kerr, T. (2011). Reduction in overdose mortality after the opening of North America's first medically supervised safer injection facility: A retrospective population-based study. The Lancet, 377 (9775), 1429- 1437. 
Vol. 2, Iss/Num. 1, Spring/Printemps 2013

Mimiaga, M. J., Safren, S. A., Dvoryak, S., Reisner, S. L., Needle, R., \& Woody, G. (2010). "We fear the police, and the police fear us": Structural and individual barriers and facilitators to HIV medication adherence among injection drug users in Kiev, Ukraine. AIDS Care, 22(11), 1305-1313.

Montigny, L. D. Moudon, A. V., Leigh, B. C., \& Kim, S. Y. (2011). A spatial analysis of the physical and social environmental correlates of discarded needles. Health and Place, 17, 757-766.

Morissette, C., Cox, J., De, P., Tremblay, C., Roy, E., Allard, R. (...) Graves, L. (2007). Minimal uptake of sterile drug preparation equipment in a predominantly cocaine injection population: Implications for HIV and hepatitis C prevention. International Journal of Drug Policy, 18, 204-212.

Popova, S., Patra, J., Mohapatra, S., Fischer, B., \& Rehmn, J. (2009). How many people in Canada use prescription opioids non-medically in general and street drug using population? Canadian Public Health Association, 100(2), 104-108.

Rehm, J., Baliunas, D., Brochu, S., Fischer, B., Gnam, W., (...) \& Patra, J. (2006). The costs of substance abuse in Canada 2002, highlights. Ottawa, ON: Canadian Center on Substance Abuse.

Ringertz, S., Høiby, E. A., Jensenius, M., Mæhlen, J., Caugant, D. A., Myklebust, A. \& Fossum, K.,2000). Injectional anthrax in a heroin skin-popper, The Lancet, 356 (9241), 1574-1575.

Roy, E, Arruda, N., Vaillancourt, E., Boivin, J., Morissette, C., Leclerc, P. (...) \& Bourgois, P. (2012). Drug use patterns in the presence of crack in downtown Montreal. Drug and Alcohol Review, 31, 72-80.

Sarang, A., Rhodes, T., Sheon, N., \& Page, K. (2010). Policing drug users in Russia: Risk, fear,and structural violence. Substance Use \& Misuse, 45, 813-864.

Shannon, K., Kerr, T., Allinott, S., Chettiar, J., Shoveller, J., \& Tyndall, M. W. (2007). Social and structural violence and power relations in mitigating HIV risk of drug-using women in survival sex work. Social Science and Medicine, 66, 911-921.

Silverman D., \& Marvasti, A. (2008). Doing qualitative research: a comprehensive guide. Los Angeles, CA: Sage Publications.

Small, M., L. (2009). 'How many cases do I need?': On science and the logic of case selection in field-based research. Ethnography, 10(1), 5-38.

Small, W., Kerr, T., Charette, J., Schechter, M. T., \& Spittal, P. M. (2006). Impact of intensified police activity on injection drug users: Evidence from an ethnographic investigation. International Journal Drug Policy, 17, 85-95.

Small, W., Rhodes, T., Wood, E., \& Kerr, T. (2007). Public injection settings in Vancouver: Physical environment, social context and risk. The International Journal of Drug Policy, 18, 27-39.

Stein, M. D., Dubyak, P., Herman, D., \& Anderson, B. J. (2007). Perceived barriers to safeinjection practices among drug injectors who remain HCV-negative. The American Journal of Drug and Alcohol Abuse, 33, 517-525.

Stoltz, J. A., Wood, E., Small, W., Kathy, L., Tyndall, M., Montaner, J. \& Kerr, T. (2007). Changes in injecting practices associated with the use of a medically supervised safer injection facility. Journal of Public Health, 29(1), 35-39.

Strathdee, S. A., Patrick, D. M., Currie, S. L., Cornelisse, P. G. A., Rekart, M., Montaner, J. S. G., (...) O'Shaughnessy, M. V. (1997). Needle exchange is not enough: Lessons from the Vancouver injecting drug users study. AIDS, 11, F59-F65. 
Wall, R., Rehm, J., Fischer, B., Brands, B., Gliksman, L., Stewart, J. (...) \& Blake, J. (2000). The social cost of untreated opiate use. Journal of Urban Health, 77(4), 688-722.

Wood, E., Kerr, T., Small, W., Li, K., Marsh, D. C., Montaner, J. S. G. \& Tyndall, M. W. (2004). Changes in public order after the opening of a medically supervised safer injection facility for drug users. Canadian Medical Association Journal, 171(7), 731-734. 